\title{
A carnavalização do Nordeste no romance Sargento Getúlio, de João Ubaldo Ribeiro: revisando as identidades e desconstruindo estereótipos
}

José Lindomar da Silva ${ }^{1}$

\section{Apresentação da problemática a ser articulada}

As sociedades tradicionais do passado (entenda-se o período anterior ao século $\mathrm{XX}$ ) ganham, na contemporaneidade, uma nova configuração. Isso porque essa nova sociedade passou por consideráveis mudanças em sua organização sócio-históricocultural. Dentre os fatores que propiciou tais mudanças estão: o impacto da globalização sobre as formas de interação mercadológica, informativas e acionistas, fazendo diminuir as distâncias; o crescimento e a dispersão dos meios de comunicação, que revolucionaram o modo de transmissão de informações; o desenvolvimento de novas tecnologias; descobertas em várias áreas da ciência; entre outros aspectos que as sociedades contemporâneas se esforçam para alcançar e ampliar. Todas essas modificações têm influenciado diretamente as relações sociais do homem com o meio e, consequentemente, a construção de sua identidade.

Na tentativa de lançar uma luz sobre essas questões polêmicas, no tocante a construção da identidade na pós-modernidade, Woodward (2000, p. 29) oferece contribuições significativas quando assinala que: “[...] as crises globais de identidade

\footnotetext{
${ }^{1}$ Mestrando em Letras, na linha de pesquisa Discurso, Memória e Identidade-Departamento de Letras Vernáculas, ambos pela Universidade do Estado do Rio Grande do Norte.
} 
têm a ver com aquilo que Ernesto Laclau² chamou de deslocamento. As sociedades modernas, ele argumenta, não têm qualquer núcleo ou centro determinado que produza identidades fixas, mas, em vez disso, uma pluralidade de centros". Partilhando dessa mesma ideia, Hall (2006, p. 17) pontua que “[...] o deslocamento tem características positivas. Ele desarticula as identidades estáveis do passado, mas também abre a possibilidade de novas articulações: a criação de novas identidades, a produção de novos sujeitos [...]". Estes apontamentos estão, ainda, imbricados nos discursos de Bauman (2005), quando este define a sociedade pós-moderna (globalizada) de "modernidade líquida", em oposição às sociedades "sólidas", tradicionais. Em seu fio discursivo ele afirma que "[...] no admirável mundo novo das oportunidades fugazes e das seguranças frágeis, as identidades ao estilo antigo, rígidas e inegociáveis, simplesmente não funcionam". Sendo assim, as subjetivações dos sujeitos possui uma relação estreita com as transformações sociais, as quais produzem um ambiente heterogêneo para possíveis representações identitárias.

As abordagens teóricas elencadas anteriormente migram, de forma explícita, para o campo literário, já que, como afirma Candido (2000), a literatura mantém estrita relação com o contexto sócio-histórico que a circunda. Essa transposição temática tem influenciando, entre outros aspectos, a forma como os escritores constroem as particularidades de seus personagens. Na literatura brasileira, em especial, esse descentramento e/ou deslocamento de uma identidade mestra, que subsumia a outra, começou a ser tematizado a partir da década de 30, no Modernismo, e ganha uma proporção de maior destaque na atualidade, quando os temas clássicos são abordados a

\footnotetext{
${ }^{2}$ Teórico considerado pós-marxista que discute questões políticas e sociais bem como a posição dos sujeitos nestes ambientes. Algumas de suas obras mais importantes são: Emancipação e diferença, A razão populista e Misticismo, retórica e política.
} 
partir de uma nova ótica, que se caracteriza mais pela pluralidade que pela homogeneização de determinados referenciais societários.

Esse contexto hierárquico é também a problemática que fez emergir, da literatura regionalista, as discussões sobre o Nordeste e a sua exclusão em relação ao restante do país. A sua construção foi representada mais por ideologias que interesses mútuos; um processo que possui toda a sua constituição histórica e que adquire novos moldes na pós-modernidade. Reforçando a condição na qual o Nordeste foi e ainda é, de certa forma, identificado, Albuquerque Jr (2001, p. 105) diz que “[...] este é quase sempre pensado como região rural, em que as cidades, mesmo sendo desde longa data algumas das maiores do país, são totalmente negligenciadas, seja na produção artística, seja na produção científica." A disparidade dessa região, em contraposição às demais, foi sempre ajudada pela mídia que se exime de mostrar as belezas nordestinas para construir uma imagem de secas, fome e misérias.

No entanto, os escritores no início do século XX e do Modernismo (década de 30) começaram a representar na literatura, por meio de ambientes e personagens característicos, os dois lados de uma sociedade que, como as demais regiões, possui suas belezas e mazelas, o bem e o mal, o sagrado e o profano, enfim, mostraram que a diferença existe, mas ela também faz parte da construção de suas identidades sócioculturais. Esses valores foram representados na literatura pós-moderna, comprometida com as realidades nordestinas, através do humor e da paródia, sendo o riso, ao mesmo tempo, o construtor de identidades e o destruidor de estereótipos. Então, acompanha-se um processo que se desencadeou com Euclides da Cunha, em Os Sertões, depois com Graciliano Ramos, com Vidas Secas, entre outros. Em seguida, surgem os escritores pósmodernos como Ariano Suassuna, com O Auto da Compadecida e João Ubaldo Ribeiro, no Sargento Getúlio, que conferem um estilo cômico e paródico na representação da identidade nordestina. 
Assim, verifica-se que a temática aludida tem despertado grande interesse e, consequentemente, conquistado um espaço notável nas abordagens literárias de cunho regionalista. Reafirmando a existência da carnavalização nesse contexto identitário, intenta-se, nesse estudo, observar como a identidade nordestina é representada na literatura brasileira pós-moderna. Para a realização de tal propósito, foi selecionado o romance Sargento Getúlio (2010), de João Ubaldo Ribeiro, autor de grande reconhecimento mundial e exímio representante da literatura sócio-cultural nordestina na atualidade.

Percebe-se que os discursos tradicionais sobre identidade nordestina estão presentes na literatura desde a primeira metade do século $\mathrm{XX}$, mas a carnavalização do nordeste, transfigurando as representações habituais, é vista com destaque principalmente na pós-modernidade. Por isso, reafirma-se, é de extrema importância compreender como está representada a construção da identidade nordestina, bem como verificar a desconstrução de alguns estereótipos. Essa desconstrução é possibilitada, também, pelo riso, este que, segundo Bergson (1983), deve corresponder às experiências com afinidades mútuas e, por isso, exige uma significação essencialmente social. Nessas condições, como afirma Bakhtin (1993), o riso se opõe a uma ideologia dominante.

Portanto, ao longo deste trabalho, serão feitas algumas considerações teóricas sobre a representação do nordeste e do nordestino na literatura; a identidade pósmoderna, com ênfase na valorização sócio-cultural das semelhanças e das diferenças e a carnavalização no romance pós-moderno. Por último, constroem-se as análises destacando, principalmente, a concepção sobre a morte, a "nova" paisagem nordestina, a linguagem e a desconstrução do cangaço no Sargento Getúlio. 


\section{Representações do Nordeste e do nordestino (sertanejo) na literatura}

O Nordeste sempre mereceu uma atenção particular no que se refere a sua posição em relação à elite sulista. Até mesmo porque suas várias sub-regiões receberam uma espécie de unificação ideológica que, ao longo do tempo, foram ganhando corpo em forma de denúncias nas escritas literárias.

De acordo com Galvão (1976), a partir da segunda metade do século XIX as representações do Nordeste (através do Sertão, considerado sua sub-região menos provida de riquezas) fazem surgir, na literatura, uma temática nova que ganha espaço e proeminência no romance. Os seus primórdios são apontados por Lacerda (2008) na publicação do romance Inocência, 1872, de Visconde de Taunay, quando o sertão e o homem sertanejo recebem os primeiros olhares. O espaço dessa representação inicial foram os conflitos fronteiriços entre São Paulo, Minas Gerais, Goiás e Mato Grosso. Em seguida, O Sertanejo, 1875, de José Alencar, este que retrata a miscigenação, no qual surge o mestiço do "cruzamento" de branco com índio. Desse "cruzamento" nasce o arquétipo homem sertanejo forte, indestrutível. Essa obra traz para o cenário a discursão do "branqueamento da raça", problemática em torno de uma política segregativa que não encontra mais espaço na atualidade. Logo depois, surge o primeiro romance a incorporar a temática da seca e do cangaço na literatura brasileira, O Cabeleira, 1876, de Franklin Távora.

Após estas produções, o Nordeste volta ao panorama literário com a publicação de Os Sertões, 1902, de Euclides da Cunha, obra de grande destaque e que inaugura a polifonia nas narrativas modernas, com as configurações territoriais, sociais e culturais. Por todos os problemas e conflitos que enfrentava, os primeiros olhares direcionados ao Nordeste se voltaram para o Sertão. Por esse motivo, essas delineações do sertão nordestino se propagam de forma considerável nas produções literárias, e são definidas 
historicamente, por Lacerda (2008), em três momentos: (1) com a publicação de Os Sertões, de Euclides da Cunha; (2) com os autores do chamado regionalismo de trinta, a exemplo: O Quinze, de Rachel de Queiroz, 1930; Pedra Bonita, de José Lins do Rego33, 1938; Vidas Secas, de Graciliano Ramos, 1938; Seara Vermelha, de Jorge Amado, 1946; (3) com Grande Sertão: veredas, de João Guimarães Rosa, 1956. Estas representações são, na contemporaneidade, reforçadas com as publicações do Sargento Getúlio, 1971, de João Ubaldo Ribeiro; Romance d'A Pedra do Reino e O Príncipe do Sangue do Vai-e-Volta, 1971, de Ariano Suassuna, entre outros acervos que constituem uma das mais representativas visões da literatura nacional.

Conforme assinala Albuquerque Jr (1988), essa revalorização que os escritores deram ao Norte/Nordeste) se deu em oposição ao Sul/Sudeste, no qual o primeiro buscou retratar as realidades de suas origens (a seca, o cangaço, o coronelismo, o messianismo, etc) e o segundo estava preocupado com a adoração europeia.

Quando se falava em Nordeste, as imagens que se evidenciavam eram de uma paisagem completamente árida, povoada por sertanejos analfabetos que, quando sofriam com as secas, eram obrigados a se retirarem do seu berço de origem. Esta região, esquecida durante muito tempo, é a prova mais concreta das desigualdades sociais que simbolizam a elitização ideológica de uma parte do país. A única relação que o Nordeste mantinha com o Sul limitava-se aos contornos geográficos, pois política e economicamente encontrava-se marginalizada, onde as leis, os costumes e as tradições eram desconsiderados socialmente em relação ao restante do país. Sendo assim, para Albuquerque Jr:

\footnotetext{
${ }^{3}$ Em José Lins do rego, particularmente, o Sertão, sub-região do Nordeste, aparece em destaque como representação do sofrimento dos nordestinos não somente em Pedra Bonita, mas também em Menino de Engenho, Riacho Doce, Fogo Morto, Cangaceiros, entre outras obras desse renomado escritor.
} 
Quando se toma o objeto Nordeste como tema de um trabalho, seja acadêmico, seja artístico, este não é um objeto neutro. Ele já traz em si imagens e enunciados que foram fruto de várias estratégias de poder que se cruzaram; de várias convenções que estão dadas, de uma ordenação consagrada historicamente. (2001, p. 193)

Somente a partir da segunda metade do século XX é que o Nordeste ganha a devida atenção, inicialmente com a "indústria" da seca. Isso, após ter sido o alvo de representações literárias de vários romancistas e de ter sua cultura revelada na voz de grandes cantadores, a exemplo de Luiz Gonzaga. Esse reconhecimento, mesmo não se igualando às demais regiões, influenciou na forma como os escritores pós-modernos construiriam suas representações nordestinas. O objetivo, agora, é mostrar não apenas o Nordeste, seu povo e sua cultura, mas também apresentar as mudanças significativas na "nova" região. Entre as abordagens nordestinas, no romance pós-moderno, está a desconstrução de estereótipos mumificados pelas reproduções (principalmente midiáticas) unilaterais. Desse modo, o Nordeste passa a ser (re)conhecido, aos poucos, como membro da diversidade nacional.

Assim, passa-se a enxergar um Nordeste que se estende ao litoral, com campos verdejantes. O nordestino forte e animalizado é também sensível e sentimental. O cangaço ganha nova interpretação, o militarismo passa a temer as línguas da imprensa e as forças federais, a linguagem cada vez mais se acentua como a marca de uma cultura nacional variada. Enfim, estas questões presentes no Sargento Getúlio, de João Ubaldo Ribeiro, mostram as raízes de uma cultura heterogênea, bem como a quebra de

\footnotetext{
${ }^{4}$ O termo "indústria da seca" foi utilizado inicialmente por Albuquerque Jr (1988) em sua dissertação de mestrado, referindo-se aos primeiros investimentos aplicados ao Nordeste que foram designados, justamente, na tentativa de amenizar os efeitos das secas.
}

Brasiliana - Journal for Brazilian Studies. Vol. 3, n.1 (Jul. 2014). ISSN 2245-4373. 
paradigmas enraizados que suplantaram a história do Nordeste nos seus aspectos sociais, históricos, políticos e culturais.

\section{Identidade pós-moderna: valorização sócio-cultural das semelhanças e das diferenças}

As transformações sociais ocorridas ao longo dos tempos provocaram mudanças significativas nos modos de identificação dos sujeitos em sua sociedade. Essas alterações pós-modernas influenciaram os campos da política, da religião, da cultura e das fronteiras sociais em tempo e espaço. Com isso, abrem-se caminhos para novas visões que preservam os valores tradicionais bem como os contemporâneos. É a (re)significação sócio-cultural através do (re)conhecimento das diferenças sem negar as semelhanças para a construção da identidade. Assim, “[...] as subjetividades se constituem a partir de referentes sociais - no sentido de que novas formas societárias implicam sempre a gestação de novos modos de organização da identidade [...]" (Severiano; Estramiana, 2006, p. 17).

Sobre as questões teóricas concernentes à pós-modernidade, Hutcheon (1991, p. 40) pontua que o modelo paradoxal nessas representações “[...] teria a pretensão de abrir qualquer poética do pós-modernismo a elementos plurais e contestatórios sem reduzilos ou recuperá-los necessariamente". Para tanto, o que se pretende com esse tipo de abordagem é a imparcialidade, a fim de identificar possíveis verdades (já que não existe verdade mestre). Esse movimento é ainda, “[...] ao mesmo tempo, acadêmico e popular, elitista e acessível" (Hutcheon, 1991, p. 40).

O romance pós-moderno apresenta, pois, toda a pluralidade narrativa capaz de mostrar em suas representações a dualidade paradigmática que permeia a sociedade atual. Hutcheon (1991, p. 84) destaca estas questões quando diz: 
Assim como grande parte da teoria literária contemporânea, o romance pós-modernista questiona toda aquela série de conceitos interrelacionados que acabaram se associando ao que chamamos, por conveniência, de humanismo liberal: autonomia, transcendência, certeza, autoridade, unidade, totalização, sistema, universalização, centro, continuidade, teleologia, fechamento, hierarquia, homogeneidade, exclusividade, origem.

Ao se questionar toda essa gama de preceitos, pode-se debruçar com o conceito de identidade traçado por Hall. Ele assegura que “a identidade é realmente algo formado, ao longo do tempo, através de processos inconscientes, e não algo inato. [...] Ela permanece sempre incompleta, ela está sempre em processo, sendo formada" (Hall, 2006, p. 38).

Portanto, as questões de identidade na pós-modernidade estão imbricadas na sociedade e na cultura de seu povo de tal forma que seria, praticamente, impossível qualquer forma de dissertação sobre esse tema sem considerar a heterogeneidade que o circunda. Quando se fala em heterogeneidade, fala-se, ao mesmo tempo, de semelhanças e diferenças, e isso implica relações de poder que vão além da superfície discursiva. Partilhando dessa mesma ideia, Silva (2000, p. 81) profere que "a identidade, tal como a diferença, é uma relação social. Isso significa que sua definição - discursiva e linguística - está sujeita a vetores de força, a relações de poder. Elas não são simplesmente definidas; elas são impostas. [...] Elas são disputadas". Todos esses questionamentos são reveladores de sociedades, culturas, políticas e crenças que se (re)significam no cenário atual, mas principalmente são fomentos para o início da desconstrução de velhos estereótipos que perpetuaram por tanto tempo nos discursos sociais, populares e acadêmicos.

Brasiliana - Journal for Brazilian Studies. Vol. 3, n.1 (Jul. 2014). ISSN 2245-4373. 


\section{A carnavalização no romance pós-moderno: $\mathrm{o}$ riso e a paródia identificando e esfacelando estereótipos}

A maioria das sociedades sempre foram marcadas por seguirem padrões preestabelecidos nas esferas sociais, políticas, culturais e religiosas. A homogeneização nestas instâncias possuía enorme carga ideológica. Contudo, a partir da Idade Média, a oficialidade das sociedades e de sua cultura elitista cede lugar a carnavalização e ao riso popular que contagiam as praças públicas. Neste contexto, os aspectos cômicos e paródicos passam a representar uma nova possibilidade de inclusão dos que estavam à margem e desestabilizar os arquétipos existentes. A esse respeito, Bakhtin (1993, p. 7) diz que "o carnaval é a segunda vida do povo, baseada no princípio do riso. É a sua vida festiva. [...] As festividades são uma forma primordial, marcante, da civilização humana". Além disso, “[...] tiveram sempre um conteúdo essencial, um sentido profundo, exprimiram sempre uma concepção do mundo". As teorias bakhtinianas (em um estudo sobre a cultura popular na Idade Média e no Renascimento, especificamente, em François Rabelais) sobre o riso e a carnavalização mostraram que as representações carnavalizadas deram origem ao que se chamou de realismo grotesco.

O realismo grotesco, como filho legítimo da carnavalização, é descrito por Bakhtin (1993, p. 27) como o "tipo específico de imagens da cultura cômica popular em todas as suas manifestações". Logo, o riso, a ironia, a paródia e o sarcasmo são elementos fundamentais para evidenciar tais imagens. Sobre essas categorias da cultura popular Alavarce mostra que:

A ironia, a paródia e o riso atuam, nos textos literários, na grande maioria de suas ocorrências, com o objetivo de suspender a censura e de 
burlar as prisões dos discursos monofônicos e consequentemente autoritários. Isso é possível porque as modalidades em questão privilegiam a polifonia e o elemento dissonante, legitimados pelo contraste de idéias (sic), traço comum entre esses três tipos de discurso. (2009, p. 12)

Dessa forma, a carnavalização, o riso, a paródia e as demais categorias que podem ser vistas no romance pós-moderno servem para representar uma época onde não há mais lugar para heróis. Ao tomar, por exemplo, o riso através de Sancho Pança (fiel escudeiro de Don Quixote) vê-se uma terrível crítica ao romance de cavalaria, no qual a figura pançuda, como sugere o próprio nome do personagem, foge ao padrão perfeccionista do herói clássico; ao dar risada de um bêbado mostra-se a contradição que aquela figura representa em oposição ao restante da sociedade, supostamente, sóbria; quando um comediante se apresenta em um programa de TV e narra fatos do cotidiano, através de sua interpretação cômica, provoca boas risadas. Bergson (1983, p. 35) diz que "a comédia é um brinquedo, brinquedo que imita a vida". Ora, se a comédia imita a vida, o riso é provocado pela ridicularização dos aspectos apresentados como padrão.

O Nordeste, por exemplo, com seu povo e sua cultura é alvo dessas representações carnavalescas pós-modernas que visam escancarar a unilateralidade social, desmontando tipos nordestinos enraizados ao longo dos tempos. Bakhtin (1993, p. 43) mostra que o riso bem como a visão carnavalesca do mundo “[...] destroem a seriedade unilateral e as pretensões de significação incondicional e intemporal e liberam a consciência, o pensamento e a imaginação humana, que ficam assim disponíveis para o desenvolvimento de novas possibilidades". 


\section{Análise da obra}

O Sargento Getúlio é, indubitavelmente, uma obra prima no que se refere à representação da sociedade e da cultura nordestina em vários dos seus aspectos. João Ubaldo Ribeiro conseguiu reunir as características mais consagradas dessa região e, consequentemente, desse povo. A leitura fascina tanto pela seriedade concernente à temática da obra quanto pela paródia humorística carnavalesca que permeia o enredo da referida narrativa.

Negar o riso, no Sargento Getúlio, significa abdicar-se do que há de mais complexo e refinado no romance. É através desse recurso que se apreende a desconstrução de alguns estereótipos nordestinos, que não encontram mais espaço na pós-modernidade.

O Sargento Getúlio apresenta as bases das teorias pós-modernas quando quebra com qualquer tentativa de definição perfeccionista sobre as noções de espaço e tempo, tanto físico quanto psicológico, pois não há limites para aprisionar os personagens. $\mathrm{O}$ objetivo é mostrar que o tempo é fluido e o espaço um horizonte sem fronteiras. Dessa forma, transita-se por uma obra na qual as suas veredas discursivas permitem viajar por diversos caminhos, dentre eles, a uma visão sobre o Nordeste pós-moderno.

\section{Concepção sobre a morte}

A morte aparece constantemente no enredo do Sargento Getúlio, tanto as mortes ocasionadas pelo próprio personagem que é um sargento, e com isso tem que cumprir ordens superiores, quanto por outras questões que são retratadas de forma carnavalizada. Os primeiros óbitos que tomamos notícia são apresentados por Getúlio no seguinte trecho: "Matei uns três infelizes assim, pelo cima de uns quipás, sendo que um chegou devagar no chão, receando os espinhos sem dúvidas. Assunte se quem vai morrer se incomoda com conforto" (Ribeiro, 2010, p. 9). 
Como se pode verificar, Getúlio fala sobre as mortes que cometeu em sua jornada como sargento de Sergipe. Logo de início percebe-se a referência feita a uma planta tipicamente nordestina, o quipá, da família dos cactos e conhecida como palmatória. Dessa forma, por meio do Sargento Getúlio, João Ubaldo destaca um dos símbolos da cultura nordestina que serviu de alimento, em tempos de seca, para muitas pessoas. $\mathrm{O}$ que chama atenção é o fato dos falecidos terem caído justamente em cima da planta que serviu para salvar muitas vidas. Sem dúvidas um ato simbólico para mostrar que a vida e a morte, em tempos passados, caminhavam com o nordestino, separadas por uma linha muito tênue.

A cena que Getúlio apresenta poderia chegar ao ápice da comoção, se não fosse o tom irônico e gozador com que ele a descreve. Vê-se a carnavalização da morte quando um dos possíveis defuntos se preocupa com os espinhos antes de cair no chão, ao mesmo tempo em que Getúlio repudia qualquer preocupação com o conforto por alguém que sentirá sua última dor.

Identifica-se, também, a intencionalidade em mostrar que não existem diferenças para os que morrem. Esse, aliás, é o único momento onde todos se igualam, sem distinções entre ricos/pobres, brancos/negros, bonitos/feios, todos descem ao mesmo nível terreno, sem incômodos ou preocupações.

Outra crítica, bem perceptível, aparece atrelada na configuração da morte relacionada ao destino. Getúlio comenta acerca da fuga daqueles por quem ele perseguia, que se lançavam ao mundo, sem rumo, fugindo do inevitável, adiando o que já estava escrito - a morte. Para Getúlio, cada um tem a sua hora e desta não adianta esconder-se.

Não tem limites para a frouxidão que faz o homem dar nas canelas e botar a alma no mundo, correndo do destino. A hora de cada um é a 
hora de cada um. O bexiguento lá estrebuchado, agora ancho nos espinhos, como se o chão fosse forrado de barriguda. Que diferença faz? Quem já viu o derradeiro tiro sabe como é. Aquela sacudida no corpo, uma estremidela de uma vez só. Depois os urubus, que a tarefa aí já não é mais de punição, é de limpeza. (Ribeiro, 2010, p. 10).

O estereótipo do destino, inclusive para a morte, é desfeito na pós-modernidade quando assume outras facetas, tais como: a livre escolha de suas ações, a infinidade de caminhos, posições e sensações que qualquer indivíduo pode optar, até mesmo o nordestino. A consciência sobre o destino, em sua grande maioria, é vista pelos seres humanos em geral como consequência de nossas próprias decisões, e não de um futuro já prescrito em páginas cujas letras são os caminhos por onde devemos seguir sem oscilar.

O que se ver, nessas sociedades cada vez mais fluidas, são seres humanos cada vez mais líquidos, adaptáveis aos diversos contextos trazidos pela globalização. O Nordeste, como membro da diversidade nacional, também está vivenciando esse processo de conscientização e mudança.

Assim como morre o sujeito que leva o tiro de Getúlio e, em seguida, os urubus vêm fazer a limpeza, também se apresenta o Nordeste atual, onde morrem os velhos estereótipos enraizados pela mídia e surge uma nova visão de mundo, conservando e valorizando ainda mais a sua cultura, a sua identidade.

Getúlio relata a morte de sua segunda vítima, que se assemelhou às demais, com exceção do detalhe desta estar rezando e mais conformada. Ele ameniza um pouco a sua culpa no assassinato levando em consideração que o indivíduo morreria de qualquer jeito, pois tinha sido picado pelo barbeiro, contudo, ainda possuía um ótimo aspecto. “O segundo cabrunquento se finou quase que do mesmo jeito, só mais conformado, 
fazendo rezas. Dizem que já estava mordido de barbeiro mesmo, morria assim ou assado qualquer dia, mas parecia cevado e sustante" (Ribeiro, 2010, p. 11).

Percebe-se a comicidade, nessa cena, pela evidência de que Getúlio fez um favor ao homem, que morreria de uma forma ou de outra. Melhor ser morto por Getúlio que morrer da picada do barbeiro. Segundo o próprio Getúlio “A morte morrida enfeia e dá sentimentos porque é devagar, não é pacífico. Sempre digo, nas festas de rua, quando o povo se junta feito besta de um lado para o outro: olhe as galinhas de Deus. Porque é igual às galinhas do quintal" (Ribeiro, 2010, p. 11). Assim, os homens são como galinhas de Deus quando estão nas festas, como se estivessem ciscando no quintal, que é o mundo. As pessoas são as galinhas e o mundo o quintal.

Atenta-se, agora, para o fato de se estar, mais uma vez, pelo menos para Deus, em pé de igualdade, em um quintal sem cobertura aos olhos divinos. Essas questões parecem ter sido trazidas ideologicamente, por João Ubaldo Ribeiro, para este cenário com o intuito de retratar a devoção religiosa dos nordestinos. Perante a religião qualquer superioridade terrena é rebaixada e, com isso, todos se tornam semelhantes à mesma imagem criadora. Essa festa, descrita na narrativa, é o carnaval que escarnece as injustiças e preconceitos contra o Nordeste e seu povo, pois somente para Deus todos são iguais, mesmo com suas particularidades culturais, sociais, hierárquicas e pessoais. Essa abordagem traz em realce a marginalização que foi direcionada ao Nordeste, quando se pensava neste como uma região desligada do resto da nação.

Getúlio mostra que os homens são como as galinhas e Deus, quando quer, pega uma e torce o pescoço. Esta é uma forma carnavalizada de representação para indicar que, em qualquer lugar do mundo, a morte está presente e nada nem ninguém foge aos olhos de Deus. Contudo, as galinhas (seres humanos) não possuem esse mesmo excedente de visão divino, esse poder para prever, antecipar ou adiar o que não se tem controle. São seres heterogêneos em sua constituição corporal, social e identitária. 
Qualquer tentativa de separação ou negação dessas características pode significar um jogo de interesses preconceituosos gerados por uma ideologia excludente.

Percebe-se a morte, ainda, através de um tom grotesco, assim como Bakhtin descreve o grotesco em Rabelais e Cervantes, imagens exageradas que ultrapassam a normalidade cotidiana, mas que não despertam medo, e sim, o riso destrutivo da seriedade dos discursos oficiais. O discurso carnavalizado, no trecho a seguir, é o dos padres que pregam sobre a morte através de palavras confortantes e motivadoras. Vejase na passagem seguinte:

Tem quem diga que a morte é calma. Tem quem diga que dá até paz, como num descanso. Só se fôr depois, porque na hora o sofrente arregala as vistas e se segura no que achar, como quem se segura na vida. E se revira e range os dentes e levanta a cabeça e puxa o ar e busca conversa e espia os lados e fica retado porque todo mundo não está indo com ele e arroxeia os beiços e faz que se senta e se esfrega em tudo e se baba e se bate dos lados e olha duro para as pessoas e dá gofadas e fica com pena dele mesmo e estica as pernas e se treme todo e faz cara de medo e se destorce e faz barulhos e se bufa e se borra e grita e pensa naquilo que nunca fez e pede a Deus nas alturas e chuta o vento e estica a roupa e incha o peito e no fim faz uma força e revira os olhos de modo medonho e dá um arranque para cima e vai embora no seu caminho, que o dia de nós todos vem. A hora de cada um é a hora de cada um. Mas ninguém gosta de ir, isso é conversa de padre. (Ribeiro, 2010, p. 2526).

Brasiliana - Journal for Brazilian Studies. Vol. 3, n.1 (Jul. 2014). ISSN 2245-4373. 
Primeiramente, Getúlio fala dos discursos sobre a morte como um descanso. Logo em seguida ele contrapõe esse fato com uma série de movimentos grotescos que o indivíduo faz durante a partida: as agonias, os lamentos, os apelos, entre outras manifestações que são parodiadas. Nota-se uma quebra de padrões ao falar sobre a morte, pois não há mais o temor em relatar sobre o que é inevitável a todo ser vivo, mas, apenas, o interesse em mostrar que o nordestino, principalmente o sertanejo, sofria de qualquer forma, ou com a vida infame que levava ou com a morte que parecia ser um alívio.

Se a morte fosse tão boa e tranquila, como pregoam os padres, o indivíduo não estaria lamentando ir sozinho e deixar os demais, que parecem ser os verdadeiros privilegiados. Com a representação dessa cena, João Ubaldo desmascara o encobrimento que justificava a morte de milhares de nordestinos castigados pela falta de assistência governamental. Os marginalizados da região Nordeste do Brasil ficaram, durante muitos anos, renegados, desmembrados da elite sulista. Por esse motivo, eram comuns os sofrimentos, as misérias, a decadência e todas as mazelas que se pode encontrar em lugares onde o descaso prevalece. Como consequência de todas as moléstias sociais relatadas morreram muitos nordestinos. Sem ter a quem recorrer, para buscar uma saída, a única alternativa desse povo era culpar o destino ou acreditar que a morte era a única solução para sanar o sofrimento, ela seria o descanso e a libertação de uma vida sem ideais.

A última cena de morte, no romance Sargento Getúlio, é a do próprio Getúlio. Assegura-se essa afirmação nas entrelinhas presente no final do seu discurso, quando sua voz é cortada. Getúlio fala que vai morrer e nunca vai morrer, pois mesmo morrendo sempre será lembrado:

[...] eu vou morrer e nunca vou morrer eu nunca vou morrer Amaro eu nunca vou morrer um aboio e uma vida Amaro aaaaaaaaaaaaaahhh 
eeeeeeeeeeeeeeeh aê aê [...] aê aê ecô ecô aê aê aê aê aê eu nunca vou morrer Amaro e Luzi netena lua essas balas é como meu dedo longe e o lhelá Ara eu vejocaju e a águacor rendode vagar e sal gadaela éboa nun cavoumor rernun caeusoueu, ai um boi de barro, aiumboi aiumboide barroaê aê aê aiumgara jauchei de barro e vidaeu sou eu e vou e quem foi ai mi nhalaran jeiramur chaai ei eu vou e cumpro e faço e (Ribeiro, 2010, p. 174).

Nessa passagem, Getúlio está em um monte na cidade de Barra dos Coqueiros, em Aracajú/Sergipe, cidade onde foi orientado a levar o preso político que trouxe de Paulo Afonso, na Bahia. Ele vê a força policial se aproximando e começa a cantar o seu aboio, por meio do qual recorda de Amaro, seu melhor e talvez único amigo e de Luzineta, a mulher com quem tinha um caso amoroso. Ambos mortos nas lutas que enfrentou pelo trajeto de sua jornada sem fim, ou como diz João Ubaldo no início do romance, em sua história de $\operatorname{aretê}^{5}$. O canto de Getúlio vai se dissipando e se misturando, tornando-se quase incompreensível, mas ainda pode-se apreciar a descrição que ele faz de Aracajú, de tempos passados em Laranjeiras e, finalmente, do seu desejo irrepreensível de cumprir com a sua tarefa. Esta é, inclusive, suas últimas palavras antes de ser morto pela força policial. A morte de Getúlio não é anunciada e, tampouco, fica expressa de forma clara, mas deduz-se esse apontamento pelo seu discurso silenciado após a vinda da força policial de Aracajú.

A morte de Getúlio representa o extermínio do velho e o nascimento do novo nordestino, igualmente rico em sua cultura, mas renovado em sua identidade. Identifica-se o nordestino não mais, e tão somente, pela sua localização geográfica, pelo

\footnotetext{
${ }^{5}$ A comparação que João Ubaldo Ribeiro faz com Aretê (deusa da virtude), deve-se ao fato de Getúlio ter a sua missão como algo pessoal, uma questão de honra e, não mais, uma simples obrigação.
} 
seu linguajar "errado", pelas mazelas da seca ou por suas remessas de retirantes. A identidade nordestina pós-moderna é vista, entre outros modos, pela sua diversidade paisagística, que se divide entre caatinga e litorais, por seu povo, cujas mudanças ocorridas lhes propiciou acesso a algumas das melhores universidades do país e por sua participação, cada vez maior, no comércio, na agricultura e na indústria nacional e internacional.

\section{A nova paisagem nordestina}

Getúlio relata os deslocamentos necessários para aprisionar alguns dos fugitivos fora da lei, pois a "gota serena não é fixe". O motivo de suas atitudes se deve ao interesse em não deixar proliferar tamanha desordem, já que isso se transformaria em outras mazelas. É assim que Getúlio justifica as suas prisões ou mortes. Em seu trajeto veem-se todos os tipos de paisagens pelo extenso Nordeste:

A gota serena é assim, não é fixe. Deixar, se transforma-se em gancho e se degenera em outras mazelas [...].De Paulo Afonso até lá, um esticão, inda mais de noite nessas condições. Estrada de carroça, peste. [...] Própria e Maruim, já viu, poeiras e caminhãos algodoados, a secura fria. E sertão do brabo: favelas e cansançãos, tudo ardiloso, quipás por baixo, um inferno (Ribeiro, 2010, p. 9).

Entre as paisagens que se pode encontrar no Nordeste vê-se a primeira delas, que se estende de Propriá à Muruim, onde, segundo a narração de Getúlio, pode-se avistar um sertão forte, secas, favelas, entre outras desagradáveis e decadentes situações. Essa 
representação sertaneja faz parte da região Nordeste, mas não representa a sua totalidade.

Mais a diante, as paisagens secas dão lugar a um ambiente completamente diferente, com vegetações verdejantes e um clima extremamente agradável.

Diga se não é Sergipe o meio do mundo? Se não é aqui as grandes belezas e os verdes matos, que chão. Se aqui não temos tudo e preferimos ficar aqui? Diga se não é. Posso ser o reis do Congo. Tocando porca. Fazendo o sete pelo quatro. O diabo. Vezes que me sinto solto, almirante de mourama, reis dos mouros, reis dos mouros. (Ribeiro, 2010, p. 42).

O estado de Sergipe é o lugar escolhido para a realização da paródia geográfica, pois, como foi visto anteriormente, há sub-regiões nordestinas com clima seco e desprovidas de riquezas, mas existem outras, como Sergipe, que possuem grandes belezas, matos verdes, onde se tem de tudo (representando a fartura). O lugar descrito é tão agradável que Getúlio se sente um rei. O título que o personagem descrito atribui a si mesmo é um símbolo da nobreza, uma forma carnavalizada de mostrar que, assim como o Sul, o Nordeste também possui seus atrativos e não pode ser, simplesmente, desligado do restante do país por questões preconceituosas e ideológicas.

Ainda fazendo referência a desconstrução dos estereótipos nordestinos, Getúlio fala sobre o rio Morcego, no qual é ressaltada a figura grotesca do Major Jacaré, também uma representação simbólica com o objetivo de mostrar que nem todas as regiões ou sub-regiões nordestinas possuem a mesma sorte no que se refere à falta de água, comida, entre outras necessidades. Comprova-se o exposto anteriormente quando se identifica a grande quantidade de água que possui o rio, o qual, com a saída do Major 
Jacaré de dentro de suas águas, levanta uma onda tão grande que fica maior que o São Francisco:

Ou assim: quando o rio Morcego está cheio e todos estão desprecatados, ouvindo as águas desaguando e sentindo o cheiro da terra molhada e aguardando tanajuras e qualquer coisa nesse sistema, quando é que me pula de dentro do rio o Major Jacaré com os peixes tudo saltando pela barba dele e quando ele sai levanta uma ôndia que o rio fica maior do que o São Francisco [...]. (Ribeiro, 2010, p. 160).

Esse fenômeno - peixes que saltam da barba do Major Jacaré - parodia a fome através da abundância de comida que supre com as necessidades do povo da região descrita, desmascara outra realidade infame que era direcionada ao Nordeste de forma homogênea. Sabe-se que esse problema - a fome - não é de exclusividade da região nordestina, pois muitas cidades sulistas também enfrentam essa calamidade. A diferença é que houve, durante muito tempo, um apagamento dessas mazelas no Sul, na tentativa de se igualar aos padrões europeus. Uma espécie de adoração que começou com os colonizadores portugueses, depois com os espanhóis e se manteve mascarada por séculos na história da formação do "povo" brasileiro. Enquanto os bons olhos estavam direcionados para o Sul que, como se disse, também tinha seus problemas, o Nordeste passou a ser o depósito de todas as desgraças e adversidades pela falta de investimentos ou interesses políticos, pois era o outro lado do país, um flagelo. Por isso João Ubaldo retrata o ambiente descrito, mostrando, por meio do personagem Getúlio, o litoral de Sergipe, carnavaliza os discursos midiáticos que só exibiam desgraças e sofrimentos e, assim, desfaz o estereótipo da homogênea escassez relacionada às secas no Nordeste.

Brasiliana - Journal for Brazilian Studies. Vol. 3, n.1 (Jul. 2014). ISSN 2245-4373. 


\section{A linguagem}

A linguagem, no enredo do Sargento Getúlio, é outra representação nodal de grande importância. João Ubaldo retrata o que seria a linguagem da praça pública do Nordeste, utiliza a forma coloquial com toda a sua expressividade. Ao invés de seguir o perfil das narrativas clássicas, de linguagem polida, João Ubaldo opta por um linguajar característico do nordestino e, mais especificamente, do nordestino iletrado cujas preocupações não são com a forma, mas com o conteúdo:

Ôi Amaro, uh-uh Amaro, ô seu peste, quando um homem fala tu responde. Um dia desses com essa macriação algum macho lhe tira-lhe o fato fora, que tu só vai ter tempo de espiar as tripas, rezar meia salverrainha, um quarto de atodecontição e escolher o melhor lugar no barro para se ajeitar, e ligeiro ligeiro, que possa ser que antes de chegar já tenha ido (Ribeiro, 2010, p. 12).

A escrita de João Ubaldo é uma reprodução fiel da oralidade de Getúlio que, por sua vez, corresponde a uma representação cultural do linguajar nordestino. Isso não significa que todos os nordestinos falem dessa forma, mas a ênfase sobre a configuração dessa linguagem justifica-se pela importância de se ressaltar as expressões e sotaques do nordestino como membro da diversidade nacional e possuidor de uma cultura única, constituinte de sua identidade.

Além da representação fiel da linguagem tipicamente nordestina, encontra-se também uma comparação com outras falas, inclusive alusões a sotaques característicos 
da região Sul. No trecho abaixo poderá ser visto o posicionamento de Getúlio frente a uma mulher, cujo acento fônico faz referência aos indivíduos naturais do Rio de Janeiro:

A dona da casa falando carioca, parecia até coisa que prestasse. Tárcio segurou ela pelo quengo e jogou lá dentro. Pensa que calou a boca? Ficou lá saturando a paciência, de maneiras que Tárcio foi e arregalou o olho cego em cima dela e soltou um bafo nela: não arrelia, mulher dama! Já se viu mulher dama ter querer, onde já se viu. Quando o diabo não vem, manda o secretário. Essa carioca sibite, acostumada a ver todo bichinho ximando o rabo dela. Sai, sai. Vasta, puta! (Ribeiro, 2010, p. 19).

A dona da casa, a que se refere Getúlio, possui um sotaque carioca. Ele ressalta, ironicamente, a importância do seu acento fônico, pois a insignificância da mulher se contrapõe ao modo valorativo com que utiliza determinada pronúncia. Ao mesmo tempo, pode-se identificar outro aspecto em forma de paródia, levando em consideração que a mulher descrita foi reprimida de forma assustadora por Tárcio, após querer se sobrepor com sua linguagem, parecendo "coisa que prestasse".

Através do humor presente no vocabulário dos carnavais da praça pública (palavras injuriosas, palavrões, ofensas, apelidos), o linguajar e a importância da mulher carioca são escarnecidos e, assim, o riso presente rebaixa o prestígio dela e de sua linguagem diante de Getúlio e Tárcio, estes com seus coloquialismos informais. Neste caso, o alto torna-se baixo. Este recurso também foi visto por Bakhtin em Rabelais, quando as figuras importantes eram destronadas e cediam lugar para aquelas consideradas inferiores. Uma espécie de destronamento no qual se terrificam todas as representações sociais e, desse modo, se extingue qualquer sobreposição.

Brasiliana - Journal for Brazilian Studies. Vol. 3, n.1 (Jul. 2014). ISSN 2245-4373. 


\section{A desconstrução do cangaço}

O Nordeste sempre foi sinônimo de cangaço, grupo de pessoas sem leis e agindo por conta própria, fazendo justiça comas próprias mãos. Os cangaceiros eram conhecidos por grande devoção aos santos e por sua aversão à polícia, que os tratava como animais selvagens. Eles também não gostavam de políticos, pois viam estes como os responsáveis por toda a desordem e falta de assistência para com os marginalizados. Mas, acima de tudo, os cangaceiros eram identificados em virtude do gosto pela profissão, por não ter piedade com aqueles que recebiam seu destino. No Sargento Getúlio, mostra-se completamente o oposto dessa situação:

Não gosto desse serviço, não gosto de levar preso. Avexa-me. Depois que levar vosmecê lá, assento os quartos num lugar e largo essa vida de cigano. Só se doutor Zé Antunes pedir muito. Mesmo assim. Me aposento-me. Essa água está quente na garrafa, mas está boa. Nunca beba água onde não pode ver o purrão. Segundo preceito. Lampião andava com uma colher de prata no embornal. Todo de comer enfiava colher. Se a colher empretecia, tinha veneno, isso porque o veneno descurece a prata, não sabe vosmecê. Morte certa para o dono da casa. Se não empretecia, dava até presentes, sortia bodegas, fazia felicidades. Muitas vezes ficava arreliado por qualquer coisinha. (Ribeiro, 2010, p. 13).

Entende-se que Getúlio leva o preso político não por gostar de seu ofício, mas por estar recebendo ordens de seu superior. Ele expressa o desejo em deixar de ser sargento após cumprir com a tarefa e aposentar-se, viver uma vida tranquila. Getúlio faz referência a 
seu patrão Acrísio Antunes (Zé Antunes), pertencente à frente política do PSD em Aracajú. As relações, nesse caso, já não são mais de cangaço, e sim de interesses políticos, pois o preso que Getúlio leva é adversário partidário.

Destacam-se também algumas ações feitas por Lampião, o cangaceiro mais famoso de todos os sertões. As referências feitas a ele são apresentadas em tempos passados (andava, enfiava, dava, sortia, fazia, ficava), propondo o entendimento da extinção definitiva do cangaço e, consequentemente, do cangaceiro. Essa inferência se reforça ainda mais no trecho que se segue:

Eu fico pensando assim aqui de preto se eu fosse para o cangaço, se tivesse cangaço. Antigamente, eu tinha raiva de cangaceiro, acho que até ontem, tresantonte, antes do antes, mas agora não tenho mais, que é que eu posso fazer. Pois podia ser do cangaço, apois, se tivesse cangaço. Como não tem, fico aqui. Ô Amaro, iú, ô fulô, se eu fosse Lampião tu ia ser Maria Bonita? Olhaí, hum. Disse uma vez, digo duas e três, que tu é frouxo por demasiado, fica aí mastigando essa lasca de couro parecendo um bode, homem creia. (Ribeiro, 2010, p. 127).

Getúlio pensa em ir para o cangaço, mas, como ele mesmo fala, não há mais esse tipo de espaço. Ele até sentia raiva de cangaceiro, porém não sente mais. É, no mínimo, curioso que um sargento expresse o desejo de ser cangaceiro, mesmo sabendo que os responsáveis por manter a ordem nunca se deram bem com aquele povo que agia por conta própria. Essa ocorrência burla as leis naturais e perturba a normalidade cotidiana. O objetivo, nesse caso, é mostrar que nada permanece estável e as posições podem se inverterem de acordo com as vontades dos indivíduos, quaisquer que sejam eles. 
Enfim, o desejo de Getúlio pelo cangaço é frustrado por dois motivos: primeiro, como já foi exposto, não há mais o cangaço; segundo, Amaro, o seu fiel escudeiro, era muito frouxo e só poderia ser Maria Bonita, mulher de Lampião. Claro que a comparação de Amaro com Maria Bonita é mais uma forma carnavalizada de desconstrução do cangaço. Algo parecido com a comparação paródica de Sancho pança, fiel escudeiro de Dom Quixote, com um cavaleiro dos romances de cavalaria, heróis esbeltos, fortes, cultos, etc. A oposição nos dois casos promove, através do humor sarcástico, a quebra dos padrões e, posteriormente, a desconstrução do cangaço/cangaceiro, no primeiro caso, e do herói perfeito nos romances de cavalaria, no segundo caso.

\section{Ponderações finais}

Para estas considerações finais, pretende-se deixar em evidência os resultados mais expressivos da nossa pesquisa. O primeiro deles diz respeito à importância que teve o romance moderno na pós-modernidade, pois trouxe uma nova visão sobre temas que há muito se discute. Essas representações, influenciadas também pela globalização, mostraram uma remodelada organização social. Além disso, o próprio romance pósmoderno, por sua quebra com padrões da estética clássica, buscou nas margens da sociedade uma forma de desmascarar as injustiças por meio da abordagem de heróis livres, sem compromissos com a linguagem, a estética, ou qualquer outra barreira que destrua a proximidade entre representação literária e sociedade.

É nesse contexto que João Ubaldo Ribeiro, através do Sargento Getúlio, utiliza-se da arte literária para mostrar o Nordeste com os olhos do nordestino. Dessa forma, busca desconstruir alguns estereótipos que se consagraram nos discursos midiáticos, populares e, até mesmo, acadêmicos. A tarefa representativa de João Ubaldo seria 
trágica se não fosse cômica, pois as relações entre Getúlio, Amaro e o preso político, principalmente, formam uma das mais complexas e instigantes comédias literárias. Claro que, acoplada a toda a comicidade da obra, observa-se também a seriedade e a necessidade em mostrar questões ideológicas que sempre permearam na exclusão do Nordeste em relação ao restante do país.

Todas as questões elencadas até aqui, João Ubaldo conseguiu expor através de um enredo carnavalizado, onde o riso e a paródia atuam como demolidores dos velhos padrões sociais e literários, que viam ideologicamente o Norte/Nordeste como um intruso nacional de hierarquia inferior frente ao Sul/Sudeste, com características europeias. Logo, por meio desse recurso que vem desde a cultura popular da Idade Média e do Renascimento, João Ubaldo consegue desconstruir o estereótipo do cangaceiro, das secas, da homogeneização nordestina em relação às paisagens, à linguagem e ao clima. Portanto, mostra uma cultura heterogênea formada por identidades igualmente diversas que evoluíram juntamente com a sociedade nordestina.

Deixa-se em aberto, portanto, a necessidade de outros trabalhos que busquem retratar o Nordeste e o nordestino na pós-modernidade, desconstruindo estereótipos que não se encaixam mais nos padrões identitários atuais. Para esse tipo de pesquisa contribui, incisivamente, as bases populares, de origem cômica, na qual a carnavalização atua desmascarando e libertando toda e qualquer tentativa de aprisionamento ideológico-social marginalizante.

\section{Referências}

Alavarce, C. S. A ironia e suas refrações: um estudo sobre a dissonância na paródia e no riso. São Paulo: Cultura Acadêmica, 2009. 
Albuquerque JR, D. M. Falas de astúcia e de angústia: a seca no imaginário nordestino - de problema à solução. (Dissertação de mestrado). Campinas: UNICAMP, 1988. Disponível em: http://cutter.unicamp.br/document/?code=000017925. Acesso em: 5 dez. 2012.

A invenção do nordeste e outras artes. Prefácio de Margareth Rago. - 2ª Ed. Recife: FJN, Ed. Massangana; São Paulo: Cortez, 2001.

Bakhtin, M. M. A cultura popular na Idade Média e no Renascimento: o contexto de François Rabelais. Yara Frateschi Vieira (Trad). 3aㅡ ed. São Paulo: HUCITEC; Brasília: Editora da Universidade de Brasília, 1993.

Bauman, Z. Identidade: entrevista a Beneditto Vecchi. Rio de Janeiro: Jorge Zahar, 2005.

Bergson, H. O riso: ensaio sobre a significação do cômico. 2ª ed. Rio de Janeiro: Zahar Editores, 1983.

Cândido, A. Literatura e sociedade: estudos de teoria e história literária. $8^{\mathrm{a}}$ Ed. São Paulo: T. A. Queiroz, 2000.

Galvão, W. N. Insidiosa presença. In: . Saco de gatos: ensaios críticos. $2^{\underline{a}}$ ed. São Paulo: Duas Cidades, 1976. p. 65-86.

Hall, S. Identidade cultural na pós-modernidade. 11. ed. Rio de Janeiro: DP\&A, 2006.

Hutcheon, L. Poética do Modernismo: história, teoria, ficção. Ricardo Cruz (Trad). Rio de Janeiro: Imago Ed, 1991.

Lacerda, A. G. D'Os Sertões ao Grande Sertão: veredas discursivas. XI Congresso Internacional da ABRALIC: Tessituras, Interações, Convergências. USP, São Paulo, 13 a 17 de julho de 2008. Disponível em: http://scholar.google.com.br/scholar?hl=ptBR\& $=$ D \%E2\%80\%99Os+Sert\%C3\%B5es+ao+Grande+Sert\%C3\%A3o\%3A+veredas+discu rsivas\&btnG=\&lr=. Acesso em: 3 dez. 2012.

Ribeiro, J. U. Sargento Getúlio. 5ª ed. Rio de Janeiro: Objetiva, 2010.

Severiano, M. F. V; Estramiana, J. L. A. Consumo, narcisismo e identidades contemporâneas: uma análise psicossocial. Rio de Janeiro: Ed UERJ, 2006. 
Silva, T. T. A produção social da identidade e da diferença. In: Silva, Tomaz Tadeu (Org.) Identidade e diferença: a perspectiva dos estudos culturais. Petrópolis, RJ: Vozes, 2000.

Woodward, K. Identidade e diferença: uma introdução teórica e conceitual. In: Silva, Tomaz Tadeu (Org.) Identidade e diferença: a perspectiva dos estudos culturais. Petrópolis, RJ: Vozes, 2000. 